\title{
Individual Educational Program (Iep) On Children With Special Needs
}

\author{
${ }^{1}$ Ervina M.R.Siahaan, ${ }^{2}$ Rinesha Siahaan \\ ${ }^{1}$ Department of Psychology, University HKBP Nommensen Indonesia \\ ervinasiahaan@uhn.ac.id \\ ${ }^{2}$ Department of Special Education Santo Nicholas School Indonesia \\ siahaanrinesha@gmail.com
}

\begin{abstract}
Children with special needs are those who require special educational and treatment as to develop humanity potential in themselves. One of the methods which can be carried out is Individual Educational Program (IEP). Individual Educational Program is a learning program designed to assist children with special needs based on strength they possess. The creation of IEP requires cooperation between professionals as well as parents. So, such program can run. The creation of IEP begins with data intake, assessment, program design, implementation and evaluation. IEP intended for special needs children must be designed correctly and written as a document which describes learning program for them and should be a guideline in the implementation. The subject of the study were one therapist as well as parents of the autism-diagnosed child. The type of the study used was qualitative case study. This study ran for seven months starting from assessment, creation, implementation and evaluation. The study result showed the child experienced a positive development, therapist had plans in each program which would be delivered. In addition, parents could also be helped in educating the child at home due to the existence of IEP. Difficulty which occurred during IEP's implementation was both the child and the parents' boredom, feeling that it was still difficult to run the program at home because a child's behaviors differ at home as well as at the therapy center.
\end{abstract}

Keywords: children with special needs, individual educational program, parents, therapist.

\section{Introduction}

Education is the basic right of every human being in order for them to sustain their lives to be more dignified and beneficial. In this regard, all citizens are entitled to pursuing education including special need children. In the Act, Law No. 20, 2003, Article 32 Clause 1: special education constitutes education for students who have difficulty in taking part in learning process due to physical, emotional, mental and 
social disability and/or possessing special aptitude as well as intelligence (Ditjen Dikdasmen, 2007). According to Mangunsong (2009) special needs children are those who deviate from average normal children in terms of : mental characteristics, sensory, physicality and neuromuscularity, social and emotional behaviors, communication ability, or combination of two or more of the abovementioned; so long as special needs children requires modification in school assignments, learning methods or treatment in light of other aspects, which are shown to foster special needs potential and capacity.

On the other hand Wisastro (2006) suggests that extraordinary children or special needs children are the ones who have abnormality in terms of intellectuality, physicality, sociality, or emotionality, so obvious compared to development as well as growth which is regarded normal, thus he or she is unable to take education in elementary school ( Dwimarta, 2015). Therefore, it can be inferred that special needs children are those with distict traits which differ from children in common because of restriction one has thereby requiring special treatment.

In order to assist children experiencing limitation also known as special needs children, learning methods and and learning strategies which suit the needs of the children are designed. One feasibly usable educational approach for special needs children is Individual Educational Program.

\section{Individualized Educational Program (IEP)}

Individualized Educational Program (IEP) / Individual Learning Program (IEP) is a teaching program in which children get an opportunity to be able to perform tasks suited to their abilities. This program provides an opportunity for special needs students to be able to learn aligned with their needs, and ways to meet their needs must align so the children's growth is more optimal and they are able to reach the level of comprehension in learning materials that they study (Mercer \& Mercer, 1985) In organizing IEP it must be adapted to the needs and ability of each student by considering several aspects namely : learning materials to cover, formulation of the learning objectives, or specific instructional objectives to achieve, work procedure and teaching aids or mediums to be used by the students to complete assignment and supervision which is how educators have to carry out control or individual guidence for students. (Mangunsong, 2009).

This program might constitute not only long run but also short run programs. Not only does IEP coverage relate to the program to be run for the chilren but it also relates to the children education and other various aspects. The arrangement of Individual Educational Program is set up to meet the needs of every child. In developing IEP, steps to be implemented are as folow:

a. instituting a committee/team, which is tasked to organize and monitor IEP's implementation, which is comprised of: 1 . The educator and Headmaster/Head of the institution, parents/a child's guardian, 2. The children (if possible), 3. Other parties upon the requests of parents headmaster, teachers or child's guardian 
b. Meeting of IEP Committee/Team

c. Identifying student's proficiency/limitations (need-assesment), as a basis in arranging the program for a particular child

d. Program arrangement based on conditions, limitations, needs and enviroment of the special needs children

e. Placement decision whether a given child is to be placed in public school/inclusive, special needs school or other institutions

f. Developing process of IEP whose elaboration covers activities as follow:

1. Describing students detailed proficiency at the present moment in various fields

2. Specifying general specific objectives for the children to achieve/ In specifying the objectives, things to consider are:

a. Objectives must encompass functional skills which are practical and are needed by the children; both in the present period or in the future

b. Objectives cover four domains which are domestic, pastime, society dan vocational domains

c. Obejctives must fit into students' growth

d. Objectives must be realistic, meaning they must be achivable to the students

3. Determining ways to measure students' progress; including developing the measuring instrument.

This study is carried to figure out the description of using Individualized Educational Program (IEP) for special needs children. Through this study it is hoped that a new discourse on the use of Individualized Educational Program (IEP) for special needs children can be found.

\section{Setting of the study}

This research was conducted at one of the centers of therapy that is Permata Diakonia This research was conducted for six months in accordance with the program period given to children. The program is conducted by a therapist who is late in getting prior training. In this study the type of children with special needs selected were children with the category of autism.

\section{RESEARCH DESIGN AND METHODOLOGY}

\section{Respondents of the study}

The characteristics of the participants in this study are special needs educators, having experience in educating special needs children with IEP at least one year.

\section{Research Instrument}

Bogdan dan Taylor (Moleong, 2011) defines qualitative research methodology as a research method which results in descriptive data in the form of written or oral words 
from people and behaviors which can be observed. In a scientific method, qualitative research method employs narative approach which emphasizes the importance of experiences experienced by the participants (Smith, 2014).

There are two stages in narative research (Smith 2014). in nature such analysis is descriptive and the second one is interpretative.

1. Descriptive Analysis

In a descriptive analysis some things need to be performed namely : getting familiar about the use of IEP (Individualized Educational Program), collecting theoretical concepts on special needs children as well as Individualized Educational Program, conducting research participants selection, preparing Inform Consent, organizing appointment for interviews with research participants.

2. Interpretatif Analysis

Steps in the while-research stages are as follows: a) interviewing the participants, b) taking notes of the interview results of the research participants c) conducting analyses based on the interview and observation results which are found by relating narration with theoretical literature.

\section{Data Gathering Procedure}

Data collection in this study are in depth interview and observation. To supplement the data, assistive instrument is to be used, namely recording with a recorder.

\section{FINDINGS AND CONCLUSIONS}

Children with special needs have restricting conditions thus require other people's assistence. . Individualized Educational Program (IEP) is a plan/program which is tailor-made for each special child based on assessment and adjusted to the child's condition, ability, and needs (Rudiayati, 2010).

Individualized Educational Program constitutes one of the programs, which was conducted in the institution where the participant was employed. This program aimed at assisting participants in order to educate pupils/children in fostering potential they inherit. The carrying out of IEP in the participants workplace was conducted starting in late 2015

Manitoba (2010) suggests there are several stages to notice in making IEP namely establlishing committee/team which is tasked to organize the implementation of the program, IEP organizing members' meeting, identifying ability and student's limitation as program lists for the children, program arrangement based on ondition, limitation, needs and environment of the children, placement decision whether a given child is to be placed in a school, and developinng IEP process exists.

The implementation of IEP in the workplace where the participant works commenced by conducting psychological assessment firsthand in order to find out children's condition such as coginitive ability, strength and ability which need to be developed bby the children. Then meeting with the participants and headmaster proceeded in order to provide training of arranging IEP. Activities were also joined by parents 
because difference in behaviors at his/her home and at theraphy site existed, thus cohesion in future implementation was required. Then what followed was identifying students' ability and limitation by means of observing and conducting interview with their parents.

After obtaining information and data needed by the participants, then the subsequent process was to arrange program based on the children's needs. In this case, in general participants gathered to discuss programs to be run for the children. After such program takes shape then the school principal gets notified. If a go-ahead is obtained, the program will be carried out.

In this study the participant was asked to create a treatment program for the authismdiagnosed child who had difficulty in complying with social rules.

The initial step to be carried out was that participant attended an IEP training program. Afterwards, participant designed activities for the child and the rundown of the activities in tackling the issues faced by the child. After obtaining the assesment results of the child, the participant,as a therapist, arranged an appointment with the child's parents, in concert designing the program to be applied to the child. Program creation began by figuring out abilities already possessed by the child, then ensued activities plan to be performed by the child.

The design of the activities covers the activity goal, required tools, duration of running the activities and steps in implementating the activities. Once designing the program activities ended, the implementation of the activities ensued. As the carrying out of IEP came to its final stage, two evaluations were conducted, namely one to evaluate the program, the other one to evaluate the child. A form of IEP given to the child.

In regard to the results of the research according to the participant, due to IEP, the program given to the child was more structural in the implementation. In a more indepth evaluation, progress exhibited by the child was the child's ability to comply with social rules. In addition, the participant contended that this program could also be carried out by another theraphist when one theraphist could not be present to teach the child.

A study conducted by Dwimarta (2015) suggests that IEP has positive impacts in assisting special needs children when studying together with normal children in public schools. A research conducted in India by Geeta dan Palat (2006) applying IEP to slow learning children has a positive effect, in which children's ability in understanding math and reading improved.

This is also supported by study results in a literature study by Rudiyati (2010) that the development of individualized educational program (IEP) constitutes a program which is applicable as strategies in learning for special needs children. In this regard it helps eductors to adjust the program suitable to a given child. The implementing Individualized Educational Program (IEP) not only focuses on the students but also works hand in hand with parents in its implementation..

However there are some complications in implementing IEP according to participants, which are difficulty in arranging instructions to be made into IEP, the making of teaching aids for the children. Besides, according to participants children's 
mood changes as well as parents' conditions in regard to cooperating in implementing the program because different behaviors were exhibited at home.

\section{RECOMMENDATIONS}

Based on interview records and observation which were used in this study, PPI program could assist educators in this case therapists so there is a cue in teaching, which can be used by therapist in fostering children's potential. Then the method to implement for teaching the children is clearer. Next up it is to keep on track with development children show. Despite the fact that difficulties such as participant's problems in creating IEP, child's fluctuative mood, not too cooperative parents arises.

Based on the results obtained in this study, researcher wishes to point out several suggestions: participant can expand knowledge by taking parts in trainings which ca help students in learning in order to foster abilities they possess, related to teaching special needs children. For parents IEP can also be carried out at home in effect his/her growth is more optimal.

\section{REFERENCES}

Berkebutuhan Khusus" Pelatihan Pelayanan Anak komprehensif Bagi Anak Berkebutuhan Khusus di

Sekolahinklusi.http://staff.uny.ac.id/sites/default/files/pengabdian/dr-atien-nur chamidah-mdisst/mengenal-abk.pdf, diakses (2017)

Departeman Pendidikan Naisonal. (2006). Kebijakan dan Program - Direktorat Pembinaan Sekolah Luar Biasa. Jakarta: Direktorat Jenderal Manajemen Pendidikan Dasar dan Menengah

Dwimarta R. 2015. Rancangan IEP (Individualized Educational Program) bagi anak berkebutuhan khusus pada pendidikan inklusif. Prosiding Seminar Nasional Pendidikan. 21 November 2015, Surakarta. Hal 230-236

Geeta \& Ramakrishnan (2006). Effectiveness of Individualized Education Program for Slow Learners : Indian Journal of Pediatrics, vol 73

Kertu, Dantes, Suami (2015). Pengaruh Program Pembelajaran Individual Berbantuan Media Permainan Dakon Terhadap Minat Belajar dan Kemampuan Berhitung Pada Anak Kelas III Tunagrahita Sedang SLB C1 Negeri Denpasar Tahun Pembelajarn 2014/2015: e-Journal Program Pascasarjana Universitas Pendidikan Ganesha Program Studi Penelitian dan Evaluasi Pendidikan,vol.5, no.1 
Mangunsong F, (2009). Psikologi dan Pendidikan Anak berkebutuhan Khusus. Jilid 1. Jakarta : LPSP3 Fakultas Psikologi Universitas Indonesia

Manitoba (2010). Student-Spesific Planning: A Handbook for Developing and Impelmenting Individual Education Plans (IEPs) Canada: Manitoba Education

Mercer \& Mercer (1985). Teaching Student With Learning Problems.Ohio Colmbia

Moleong L.J, (2011). Metodologi Penelitian Kualitatif Edisi Revisi. Bandung: PT Remaja Rosdakarya.

Rudiyati S, (2010). Pengembangan dan Pengelolaaan Program Pembelajaran Individual "Individualized Educational Program"/IEP bagi anak berkebutuhan khusus. Jurnal Pendidikan Khusus Vol 6, 54 - 63

Smith.A. Jonathan (2014). Psikologi Kualtitatif ; Panduan Praktis Metode Riset. Yogyakarta: Pustaka Pelajar 